\title{
Understanding the Escalation of Brain Drain in Nigeria From Poor Leadership Point of View
}

\author{
Omonijo Dare Ojo \\ Covenant University, P.M.B 1023, Canaan-Land, Ota. \\ Ogun-State, South-West Nigeria. \\ E-mail: omonijoojo@yahoo.comor oyimakejo@yahoo.co.uk Tel: +234702648-0233 \&081-3385-6587
}

\section{Nnedum Obiajulu Anthony Ugochukwu}

Department of Psychology, Faculty of Social Sciences

NnamdiAzikiwe University, P.M.B.5025 Awka Anambra State, South-East Nigeria

E-mail:nneduma@yahoo.com or chineduzng@yahoo.com Tel: +2348033146636

\section{Ezeokana Jude Obinna}

Department of Psychology, Faculty of Social Sciences

NnamdiAzikiwe University,P.M.B.5025 Awka, Anambra State, South East Nigeria

E-mail:fadaezeokana@yahoo.com Phone: +23480 35446399

\begin{abstract}
Migration of people from one place to another in countries of the world in search of better conditions of living predates history. It ignited western societies' contact with Africa and the rest of the world. Prior the contact, agriculture was the main stay of Africa's economy. Thus, the movement of farmers from one location to another in search of fertile grounds for cultivation was in vogue. After independence in Nigeria, cattle rearers are known for relocating from the North to South during dry season in search of green grass to sustain their cattle and occupation. In the present day Nigeria, the same scenario still abounds but in a new dimension. It now involves movement of highly skilled manpower from the country to developed societies. Among other things, this paper finds out if there is a relationship between poor leadership of the country and escalation of brain drain. Simple percentage and ranking method was used to analyze the study's data. Chi-square was used to test its hypothesis. Our result revealed a relationship between poor leadership of the country and brain drain. It equally indicated that students are interested in travelling out of the country to developed societies after their study. Also from the study, twelve causes of brain drain were indentified. Some of them are: mass unemployment, poor salaries and conditions of service, mass poverty, crises-religious, communal, political, education etc. In respect of effects of brain drain on the nation's economy, eleven factors were identified by the respondents. Some of them are: loss of human capital assets to man various institutions in the country, loss of tax of migrated manpower to foreign countries, loss of capital invested in education of migrated manpower assets etc. Finally, eleven solutions were profiled to the lingering problem of brain drain. The most important ones are: Good leadership, salary and conditions of service as well as rewarding system for diligent staff, mass employment etc.
\end{abstract}

Keywords: Poor leadership; Brain drain; Escalation; Nigeria;

\section{Introduction}

Stenman (2006) describes brain drain as a large emigration of individuals with technical skills or knowledge from one country to another usually for better conditions of service and good living environment. These factors are germane for man and his family. The former serves as a means of livelihood while the latter makes life convenient for him and his household. Thus, every professional is 
interested in both. That is why he subjects himself to the rigor of academic activities in institutions of learning from the elementary stage to the highest level. At the end of his study, he looks for where the best salary and conditions of service can be obtained around the world. The menace of human capital flight seems to be an issue of concern to scholars across the globe; because its occurrence defiles ideological affiliation of countries worldwide as well as their level of development. In respect of ideological background, brain drain affects both socialist and capitalist nations. Socialist countries like Cuba and Russia would have been exempted from the problem, judging from the fact that they strive to build societies based on equality and humane values of living not for accumulating personal wealth but for using knowledge, skills, talents and whatever resources available to make their countries better places for entire citizenry. The paradigm being the arch rival of capitalism is expected to make its countries free from brain drain (Mghanga 2008). But the reverse is the case. The problem of brain drain is worse in some socialist countries than many capitalist states (BCC News 2002; Goodman 2007).

In term of advancement of countries worldwide, the level of development is never an antidote to human capital flight. Hence, the most developed countries of North America and Western Europe are not speared out in the scourge (Paterson 2007 and Canadian Immigration 2008). Moreover, the less developed countries of Central and Eastern Europe are not exonerated from the problem of brain drain (McLaughlin and Smith 2005). In developing countries of India, Pakistan and Middle East, outflow of professionals to Western Europe and North America is evident (BCC News 2001; Harrison 2007). Furthermore, a number of Latin America countries had, over the years, suffered a considerable loss of professionals to Western nations (World Bank 2007). In underdeveloped nations of Caribbean Islands, the menace of brain drain has prompted $80 \%$ of college graduates from Suriname, Haiti, Grenada and Guyana to migrate, mostly to the United States (Viveros and Jackson 2006). Countries of Africa are equally in the same rank with Caribbean Islands in term of underdevelopment. Nevertheless, the continent is the hotbed of brain drain in the world (Harrison 2007; Offiong 2001). Countries like Gambia, Ghana, Kenya, Sierra Leone, Uganda, Zambia and Zimbabwe are the most affected nations Carrington \& Detragiache (1998) as indicated in chart 1. South Africa, Nigeria and Ethiopia are also included in the list of affected countries in Africa (Paul et al 2004; Girma 2009).

Chart 1. The migration rates of manpower assets from Africa to the United States in 1990, by educational category

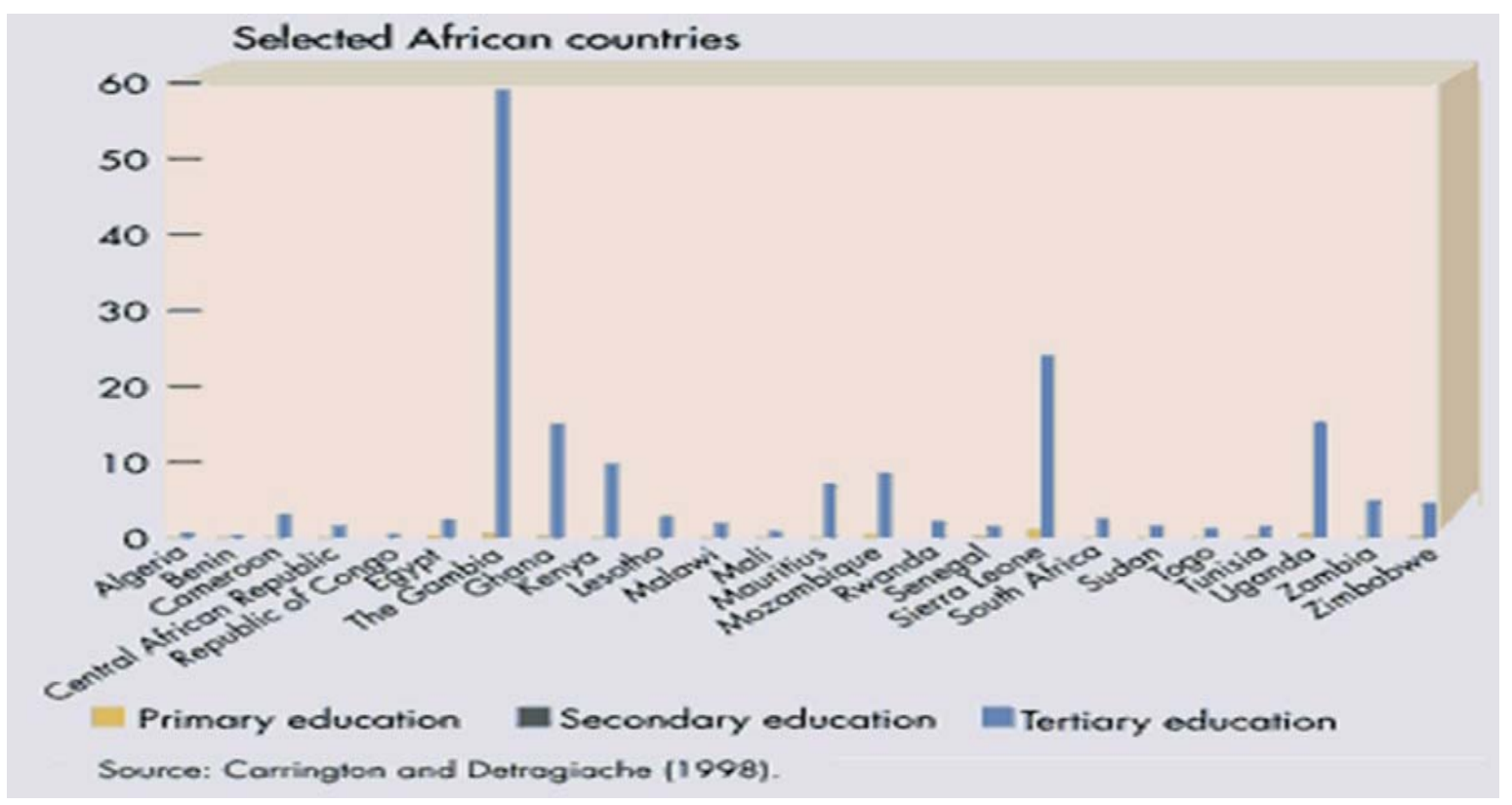

As brain drain is considered a world problem, its degree of occurrence varies from one country to another (Anekwe 2009). While its occurrence is very minimal in developed world, it is endemic in underdeveloped nations. This cannot be divorced from the fact that factors prompting brain drain in underdeveloped countries are well addressed in developed countries. The lure of well-maintained hightech facilities in rich countries, in particular, is seductive for manpower assets in underdeveloped societies (Hagopian et al 2005). Job security, prestige and high salaries prevailing in their work settings equally attract them (Hagopian et al 2005). Although, manpower assets do migrate from one developed or less 
developed country to another but the movement is not rampant. Moreover, it does not constitute a major setback to the advancement of such nations. In another development, it is observed that skilled manpower assets do migrate from developed nations to underdeveloped countries, but this could be viewed in three ways:

- They migrate to work in their nations' companies operating in underdeveloped countries. Such companies operating in Nigeria include, Shell Petroleum Development Company Limited \{SPDC\}, Chevron Nigeria Limited $\{\mathrm{CNL}\}$, Texaco Overseas, Halliburton, Julius Berger etc.

- They migrate to offer selfless services in international bodies set up to address specific social problems- war, deluge and famine etc threatening the existence of mankind in underdeveloped countries. Such bodies include UNO peace keeping force, WHO, ILO etc.

- They are coming as expatriates to tackle technological, leadership, scientific, education and economic problems of underdeveloped countries.

Nevertheless, it is obvious that manpower assets don't migrate from developed world to underdeveloped countries because of joblessness, poor salary, and condition of service etc. Thus, brain drain could be perceived as a major problem affecting underdeveloped societies. Its escalation reached an alarming rate in Nigeria in 80s, when militancy dictators (Ibrahim Babangida and Sani Abacha) and 'political profiteers' (Alhaji Umaru Dikko, late Chief Richard Akinjide, late Alhaji Bakin Zuwo, Joseph Wayas, late Chief Adisa Akinloye etc) were in power (UNDP 2001: \& The World Worst Dictators 2010). It is on the basis of identifying the relationship between poor leadership of the country and escalation of brain drain that this paper is conceived. It strives to examine factors leading to the escalation of the social problem. Equally not certain but very germane to this study is whether students who are undergoing training in the higher institutions are interested in migrating to developed countries after their study. Furthermore, effects of brain drain on the nation's economy may not have been fully established.

The study employs opinion of undergraduate students, academic and non academic staff in two selected private universities in South West Nigeria to address these social problems. The choice becomes expedient because the hope of achieving excellent education in the present day Nigeria rests heavily on private universities Aina cited in (Anugwom, Omonijo and Fadugba 2011).

\section{Hypothesis}

$\mathrm{H}^{1}$ : There is a relationship between poor leadership of the country and escalation of brain drain.

\section{Objectives of the Study}

a. To discovered if there is a relationship between the poor leadership of the country and escalation of brain drain.

b. To find out factors causing the escalation of brain drain.

c. To discover whether students who are undergoing training in higher institutions are interested in travelling to developed societies after their study.

d. To find out effects of brain drain on the economy of the country.

e. To discover solutions to the problem of brain drain.

\section{Literature Review}

\subsection{Examination of Research in Brain Drain}

The British Royal Society, views brain drain as the outflow of scientists to North America (Shin 2002). In a similar vein, UNESCO sees brain drain is an odd form of scientific exchange among states that is characterized by a movement in one direction, which inevitably flows to developed countries (http://www.sudaneseonline.com/cgi-bin/enews 2008). These two bodies view brain drain as an emigration of scientists to developed countries such as North America. But UNESCO extends the destination of these scientists to other parts of the world. Nevertheless, it could be observed that brain drain is not only flowing to one direction. It is an affair that involves different nations of the world (http://www.answers.com/ topic/braindrain. 2008). David (2005) tackles the above flaw. According to him, brain drain is an emigration of trained and talented individuals to other nations of the world. The menace is traceable to conflicts, lack of opportunity, health hazards and political imbroglio arising from 
bad leadership, prevalent in countries of origin of these manpower assets (David 2005). David's view is very comprehensive. It does not restrict brain drain to human capital in the field of medicine alone. Specialists in other areas of study in life are obviously included. Moreover, it includes various reasons behind exodus of manpower assets from one country to another. Nevertheless, the view ignored the crop of people who travelled abroad for training and acquired the necessary skill needed in their fields of specialization and stay permanently (Aredo 2008)

Johnson and Regets (1998) addressed the gap in knowledge inherent in David (2005) view. According to them, brain drain refers to the cycle of people moving abroad to study and taking a job at the end of their studies. Such circular migration is prevalent amongst Malaysians and Ethiopia who studied abroad (Aredo 2008; Smith and Favell 2006). Such students don't like coming back to their countries of origin due to the menace of brain drain. However, Johnson and Regets (1998) are found wanting for their inability to consider movement of skilled manpower from one sector of the economy or other field of human endeavour to another with the hope of securing better incomes and other benefits within a country or in another country. Encyclopedia Britannica addresses this flaw. According to the dictionary, brain drain is the "departure of educated or professional people from one country, economic sector, or field to another usually for a better pay or living conditions (http://www.sudaneseonline.com/cgi 2008:1). In Ethiopia for example, The Gondar Medical Science College reported in 2000 that it lost 25 specialists and general practitioners to private clinics and foreign employers in the previous three years (http://wwwsudaneseonline .com/cgi 2008:1).

However, movement of manpower from one job to another within a country is evident in all the nations of the world. Any manpower asset who sees a better placement in another organization moves to such an establishment when chance avails. This does not impact negatively on the advancement of such societies but the mass movement of human capitals from poor countries to rich countries does. Technologies, scientific thoughts and design methods are stored in human brain. They are only accessible to the individual involved. When such persons depart from their countries, their brains which can be used to develop their countries go along with them. Thus, their nations remain underdeveloped (Pei 2008).

\subsection{State of Knowledge on Leadership}

Leadership is one of the most observed phenomenon but least understood in human society (Burns 1998 cited in Blackaby and Blackaby 2001). Therefore, it is an issue of concern to writers worldwide. One of such is Gardner (1990). He perceives it as the process of persuasion or example by which an individual (or leadership team) induces a group to pursue objectives held by a leader and his or her followers. This perception recognizes the fact that leaders and their followers have aims which they want the ruled to obey. But it is not obvious whether such rules are to the detriment of the ruled or not. Nevertheless, the term in this context could be restricted to private organizations or parastatals where promotion of elites into leadership positions is based on qualifications and not competition through election. Mac Gregor (1998) views the concept in that direction. For him, leadership is when persons with certain motives and purposes mobilize, in competition or conflict with others, institutional, political, psychological, and other resources so as to arise, engage, and satisfy the motives of followers. This idea is comprehensive but motives of members of the clique are of paramount importance to leaders in this scenario. In this regard, interests of the ruled are not counted much. This gap in knowledge is provided for in the idea of the concept given by Our Lord Jesus Christ in (Mark 10: 42-45). According to him:

Ye know that they who are accounted to rule over the gentiles exercise lordship over them; and their great ones exercise authority upon them. But so shall it not be among you; but whosoever would be great among you, shall be your minister; And whosoever of you would be the chiefest, shall be servant of all. For even the son of man came, not to be ministered unto but to minister, and give his life a ransom for many.

Applying the above to nations of the world, two types of leaders come to mind. Firstly, leaders who wield power over the ruled. Such leaders see themselves as masters who should be served by the ruled. Secondly, leaders who minister to the ruled. Such leaders see themselves as servants of the ruled and offer themselves as ransom. The former explains leadership position in underdeveloped countries of Africa and Caribbean Island. In curt, most post-colonial leaders in Africa are modern Nero's in brutality, tyranny and self-indulgence (West 2003). Bloody dictators litter the entire black continent (Ekwueme 1994). In these parts of the world, leaders who minister to the ruled are very few. Men and women who can effectively address a multitude of societal and political ills that galvanized brain drain are very scarce. The latter characterizes leadership position in the developed world. Such leaders promote the general good rather 
than regional or personal self interest (Blackaby and Blackaby 2001). They see leadership position as an avenue to render selfless service to the public. Their personal interest is always slaughtered for public interest. This seems to have been the major reason behind the advancement of western societies.

\subsection{Examination of Research on the Causes of Escalation of Brain Drain in Nigeria}

Numerous reasons pervade literature to account for the exodus of the best minds from Nigeria to the developed world. Most of these reasons tend to be skewed towards push and pull factors that are economic and political in origin. Nevertheless, we should not lose sight of the social and psychological needs that compel human capital to seek more conducive environments for their careers and lives as well as that of their families.

Commencing from economic factor with particular reference to Marx and Engels (1969:69) “..the economic structure of society is the real foundation, which raises a legal and political structure that corresponds with definite forms of social consciousness". Therefore, whatever manifests in the superstructure is settled in the substructure under heathen wherein its strength lies. Economy is very essential in any nation, but economy of Nigeria is very poor. Consequently, the level of industrialization, which can provide job opportunities for the populace, is very low. Salaries and condition of service of workers are poor. Household incomes of many workers often drop below an acceptable level (Chandra 2008). Thus, a substantial percentage of the population is living below poverty index. Nigeria, which was one of the richest 50 countries in early 1970s, has retrogressed to become one of the 25 poorest countries at the threshold of the 21 century (Igbuzor 2007). Also, the nation hosts the third largest number of poor people worldwide, after China and India (Igbuzor 2007). Statistics show that the incidence of poverty using the rate of US $\$ 1$ per day increased from $28.1 \%$ in 1980 to $46.3 \%$ in 1985 and declined to $42.7 \%$ in 1992. Nigeria fares very poorly in all development indices. Therefore, her average annual percentage growth of GDP from $1990-2000$ was 2.4. This is very poor when compared to Ghana (4.3) and Egypt (4.6). The gross national income per capita is US $\$ 260$; under five mortality rate per 1,000 live births is 153; maternal mortality rate per 100,000 live births is 1,100; and life expectancy at birth is 46 years for males and 48 years for females (Igbuzor 2007). The Gini index for Nigeria is 50.6. This compares woefully with other countries such as India (37.8), Jamaica (37.9), Mauritania (37.3) and Rwanda (28.9) (Igbuzor 2007). The average Nigerian only consumes between 85 and 90 percent of the calories required to maintain a healthy life, a figure that has actually declined from 95 percent in the mid-1960s. Only 38 percent have access to safe drinking water. There are about 6,440 Nigerians for every doctor. In Mexico, the comparable figure is 1,242. Only about half of the Nigerian population is literate (Achebe 1984). Nigeria is on the bottom 191st position out of 192 nations with poor road network recording the highest number of deaths attributed to road accidents in the world (Oloko et al 2011; Ajayi 2011). These combined together seem to make manpower assets vulnerable to brain drain in the country.

In term of poor salaries and conditions of service, lecturers are the most affected staff in Nigeria. Within the domestic labour force, academics constitute the least paid workers as indicated in table 1.

Table 1. A Comparison of average salaries in different sectors of the Nigerian economy.

\begin{tabular}{|c|c|c|}
\hline S/n & Sector & Salary per annum $\{\mathbf{N}\}$ \\
\hline 1 & Public sector (oil) & $450,000-600,000$ \\
2 & Public sector (iron \& steel) & $300,000-400,000$ \\
3 & Nigerian economy (Average) & $100,000-200,000$ \\
4 & University academic staff & $30,000-54,000$ \\
\hline
\end{tabular}

Source: ASSU, National Secretariat Publication, cited in Oni 2010

The salary differentials between the university and other sectors of the economy prompted frustration and disillusionment among lecturers (Oni 2010). It could aggravate the menace of brain drain. To make the matter worse, salaries of their contemporaries in other African nations are much better than theirs as indicated in table 2 . 
Table 2. Academic staff salaries in selected African countries

\begin{tabular}{|c|c|c|c|c|}
\hline \multirow{2}{*}{ S/n } & \multirow{2}{*}{ Countries } & \multicolumn{3}{|c|}{ Academic staff Salaries per annum (US\$) } \\
\cline { 3 - 5 } & & Lecturer & Senior lecturer & Professor \\
\hline 1 & South & 15,000 & 30,000 & 55,000 \\
2 & Africa & 12,000 & 24,000 & 48,000 \\
3 & Zimbabwe & 3,600 & 4,800 & 6,000 \\
4 & Ethiopia & 3,600 & 4,500 & 5,400 \\
5 & Kenya & 1,800 & 3,000 & 4,800 \\
6 & Ghana & 222 & 360 & 439,2 \\
& Nigeria & & & \\
\hline
\end{tabular}

Source: ASSU National Secretariat Publication cited in Oni 2010

The pay package for a professor is about 1\% of his colleague in South Africa, 7.32\% in Ethiopia and $9.15 \%$ in Ghana (Oni 2010). Hence, some faculty abandoned academia for other sectors of the economy, where professionals and scientists received higher salaries and greater social recognition (Ogu 2008). Thus, poor salary could be a major cause of brain drain in academia in the country.

Inability to secure good employment opportunities by many young graduates to tackle their economic and social needs as indicated in table 3 could be a strong force behind their migration to developed nations.

Table 3. National unemployment rate between 2000-2009

\begin{tabular}{|c|c|c|}
\hline $\boldsymbol{S} / \boldsymbol{n}$ & Year & Rates \\
\hline 1 & 2000 & 13.1 \\
2 & 2001 & 13.6 \\
3 & 2002 & 12.6 \\
4 & 2003 & 14.8 \\
5 & 2004 & 13.4 \\
6 & 2005 & 11.9 \\
7 & 2006 & 12.3 \\
8 & 2007 & 12.7 \\
9 & 2008 & 14.9 \\
10 & 2009 & 19.7 \\
\hline
\end{tabular}

Source: National burean of statistics cited in Igwe 2011

The high rate of unemployment in Nigeria within this period is further decomposed to three groups in table 4

Table 4. Unemployment rate by educational group, age and gender (March 2009)

\begin{tabular}{|c|c|c|c|}
\hline Item & Urban & Rural & Composite \\
\hline All groups & 19.2 & 19.8 & 19.7 \\
\hline Educational group & \multicolumn{3}{|c|}{} \\
\hline Never attended & 20.6 & 20 & 20.1 \\
Below primary & 18.6 & 22.9 & 22.3 \\
Primary & 15.1 & 14.7 & 14.8 \\
Secondary & 21.3 & 25.3 & 23.8 \\
Post secondary & 13.9 & 26.4 & 21.3 \\
\hline Age group & \multicolumn{3}{|l}{} \\
\hline 15-24 & 49.9 & 39.6 & 41.6 \\
25-44 & 16.3 & 17.3 & 11.5 \\
45-59 & 10 & 12.1 & 16.7 \\
60-64 & 18.2 & 16.2 & 17 \\
\hline Gender & 17.2 & 16.9 & 23.3 \\
\hline Male & 21.7 & 23.9 & \\
\hline
\end{tabular}

Source. National burean of statistics cited in Igwe 2011 
The blow of economic downturn has badly affected young graduates and female gender in Nigeria (Igwe 2011). It could force young manpower assets-male and female to migrate to developed nations.

Directly connected to the above is the loss of status that many manpower assets suffer in societies where more value is placed on material attainments rather that educational accomplishments. It could be a contributing factor to the escalation of brain drain in Nigeria. This may not be easily ignored in Eastern Nigeria, where such manpower assets are often subject to ridicule because high value is placed on accumulation of material things that they cannot acquire with their poor remunerations. To recapture the worth of their academic achievements, they move to developed countries where they think their value can be appreciated and rewarded. The situation is worse in a culture where professionals are seeing as the bread winners of their extended families. Their inability to fulfill the expected cultural obligations may prompt them to seek better opportunities in developed countries.

Linking economic factor with political ill, it could be realized that Elites in government use politics to secure power in order to satisfy their selfish economic interests (Ake 2001; Offiong 2001). That seems to be one of the major reasons behind rigging of elections in Nigeria. It enables many elites to stay in power for long. When they are in power, they pillaged and emptied the treasury to the detriment of the poor masses (Amokeodo 2004). They demonstrate that the struggle for power among them is for sharing the spoil of political office (Osakwe 2002; Amaefule and Owete 2006). Most of these elites-Ibrahim Babangida, Sanni Abacha etc are richer than the country without any traces of notable invention.

Economic and political crises in Nigeria have resulted in riots, unrest and wars (Tettey 2007). The salvage of war seems to defile the worth of properties and manpower assets of any nation. The wealth of a country could be wiped out in a second, in the process of warfare as witnessed in industrial cities of Hiroshima and Nagasaki during Second World War in Japan (Adams and \& Crawford 2000). Also, the effect of the war on Poland's manpower assets was grievous and too costly, as 22, 000 of the best and brightest brains including an admiral, 14 generals, 24 colonels, 20 university professors, 300 physicians, several hundred of lawyers, engineers, more than 100 writers and journalists as well as 200 pilots lost their lives and talents deposited in them perished (Guardian Editorial, April 2010). Effects of the civil war between 1966 and 1972 in Nigeria were great deal in terms of lives, money and infrastructure (Alexander 1980). In term of lives, estimated three million persons died, most from hunger and disease (Alexander 1980). Apart from the above full scale war, crises in Nigeria have led to destruction of lives and properties. Such includes the Boko Haram insurgence in Borno, Yobe, Gombe, Bauchi and Kano States Farouk (2011), Zaria Shittes outbreak, Jos mayhem, Maiduguri on slaughter, Kaduna religious and Onitsha riots, Ilorin church burnings, Maitatsine insurgents, Lagos and Ijebu-ode catastrophe, Ali must go student riot of 1977, June 12 political imbroglio, militants attack on oil installations and personnel in Niger Delta (Ajayi 2009), communal clashes between Ife and Modakeke (Osun-State), Aguleri and Amuleri (Anambra-state), Ijaw-Itsekiri and Urhobo (Delta-State), Barakor and Nwebiara-Rivers-State (Ibanga 2010) etc. These could be other major reasons why manpower assets flee their homes in Nigeria for Western nations, where they think their lives could be preserved.

Security conditions continue to deteriorate in large parts of the country. The drastic level of deterioration, as reported by the United Nations High Commission for Refugees (UNHCR) 2009 edition has prompted many people to seek asylum in industrialized societies (Akande and Fagbemi 2009). UNHCR submission goes to justify the study of the World's Worst Country to live in (Reinstra 2009). The survey ranked Nigeria and many Sub-Sahara African nations the worst countries to live in worldwide. In view of this, it could be noted that worst countries are not the best places to display talents. Talents are developed, utilised and preserved in the conducive environments.

Apart from these, lack of psychological satisfaction of manpower assets with their jobs, humiliation of many manpower assets by elites in power as well as unnecessary hostility to the advancement of young and talented persons in academia and their families could add fuel to the fire of brain drain in Nigeria. Some frustrated academics, technicians and Doctors, who do not have access to relevant literature and equipment to perform their jobs at optimal levels could quit out of frustration for developed nations, where they think they could be fulfilled. The death of infrastructure in the public citadel of learning is sickening and runs short of an ideal academic environment (Onyekakeyah 2005). The National University Commission survey discovered that only about 30 percent of Nigerian student population has adequate access to classrooms, lecture theatres, laboratories, workshops and libraries (Okebukola 2002). In most universities, where computer course is offered, students graduate without touching a computer once (Onyekakeyah 2005). In the present day Nigeria, students are learning in dilapidated buildings, environmentally depressing and learning disabling situations (Odetunde 2004). These could prompt brain drain in the country. 
American Visa Lottery is another major cause of brain drain in Nigeria. The program was established in the 1996 Immigration Act of America to encourage mass movement of manpower to the United States. In the last five years, the programme has taken 36, 669 manpower assets out of Nigeria to America (United States of America Green Card 2011). The programme succeeded in recruiting this large number of personnel from the country because most of them were battered, bitten and jobless prior winning the lottery that took them to America, where they now live in good conditions (Emeagwali 2009)

\subsection{State of Knowledge on the Effects of Brain Drain on Nigerian Economy}

Brain drain is a social index. Thus, its effects could be very difficult to measure. Nevertheless, it could be seen as a devastating blow to the economy of Nigeria in term of physical cash. The United Nations Commission for Trade and Development estimated that each migrating African professional represents a loss of $\$ 184,000$ to Africa (Haines 2002). Moreover, brain drain is a loss in term of money used to employed skilled manpower from developed societies to replaced migrated manpower from underdeveloped countries. In the light of a dwindling professional sector, African institutions are increasingly dependent on foreign expertise. $35 \%$ of total ODA to Africa is spent on expatriate professionals from the west (Goodman 2008). In Nigeria, the petroleum industry hired about 1,000 of such skilled expatriates. Also, the nation use to contract out its oil exploration at the staggeringly high price of $40 \%$ of its profits to foreign oil companies. To make the matter sad for manpower at home, expatriates' are paid higher than them (Emeagwali 2009). Besides, brain drain serves as a loss to the country in term of tax earnings. Taxes of migrated human capital assets go to their resident countries (African New Service, 2000). In term of the remittance of money to Nigeria, developed nations economies are heavily benefited. For every $\$ 300$ per month a professional African sends home, that person contributes $\$ 12,000$ per month to the U.S. economy (Emeagwali 2009).

Very similar to the above is the loss of investment of the country in education. Nigeria carries the burden of investing resources in education to produce skilled manpower needed in various sector of the economy but who instead end up benefiting the development of North America, Western Europe and other less developed nations of the world, who do not pay for the education (Mghanga 2008). It takes $\$ 150,000$ to train a doctor and US $\$ 15,000$ for a university student in Africa (Ngatia in Wilson 2008). When they leave their country for developed countries after their education, Africa will lose not just the money spent on them but everything that goes with them. For instance, an African professional working in the United States contributes about $\$ 150,000$ per year to the U.S. economy and contributed nothing to the continent's advancement (Emeagwali 2009).

Apart from the loss of manpower in money, the most catastrophic consequence of brain drain in Africa is the shortage of manpower assets in all areas of human endeavours. The Economic Commission for Africa estimates that between 1960 and 1989, some 127,000 highly qualified African professionals left the continent (Tebeje 2005). The continuous outflow of skilled labour from the continent contributes to a widening gap in science and technology between the continent and other parts of the world (Tebeje 2005). In Nigeria between 1986 and 1990, 10,694 professionals from tertiary institutions alone migrated to developed countries, while those who left public, industrial and private organizations, was over 30,000 (Anekwe 2009).

The shortage of manpower assets in the country is evident in education, mostly in areas of science and technology. Tertiary institutions in the country are in mess due to the inadequacy of competent lecturers. Most of the best scholars have migrated to developed countries. The enormity of the load that few ones left behind are shouldering in respect of lecturer/student ratio can't be overemphasized. In 1997, the total number of academic staff in Nigeria was 12, 395 while that of students was 236, 261. Therefore, a lecturer/student ratio of 1: 19 should be considered much lower than the UNESCO norms of 1 lecturer to 10 students (UNESCO cited in Oni 2010). Table 5 indicates comparative lecturer/student ratio for some developed, less and underdeveloped societies of the world. 
Table 5. University lecturer/student ratio in some selected societies

\begin{tabular}{|c|c|c|c|c|}
\hline S/n & Country & No. Lecturers & No. Students & Ratio \\
\hline 1 & Nigeria & 12,395 & 236,261 & $1: 19$ \\
2 & Ethiopia & 1,440 & 26,415 & $1: 18$ \\
3 & Kenya & 4,392 & 35,421 & $1: 8$ \\
4 & Zimbabwe & 1,618 & 13,045 & $1: 8$ \\
5 & South Africa & 13,326 & 380,184 & $1: 28.5$ \\
6 & Brazil & 172,828 & $1,716,263$ & $1: 10$ \\
7 & Mexico & 72,742 & 125,207 & $1: 7$ \\
8 & Germany & 243,303 & $1,856,542$ & $1: 7.6$ \\
9 & United Kingdom & 97,274 & 923,878 & $1: 9$ \\
\hline & \multicolumn{4}{|c}{ UNESCO Norm } \\
\hline
\end{tabular}

Source: Federal Office of Statistics, Lagos cited in Oni (2010).

Dwelling on lecturer/students ratio displayed in table 5, it is obvious that an average lecturer in Nigeria carries much heavier burden than his colleague in Kenya or Zimbabwe. The norm in developed countries such as Britain, Germany and Mexico is lower than UNESCO's prescription. Therefore, lecturers in Nigeria would consider it wise to migrate to these countries because the burden of dealing with overcrowded students in Nigeria could be gladly avoided. The lecturer/student ratio is evident in nearly all courses in the country. Also, laboratories are either empty of important equipment and experimental consumables or non-existent. Libraries clamour for updating with recent materials. Teachers are badly underpaid. Most of them have abandoned academics for private industries; banks etc while many of them have had to resort to migration to other countries to keep their bodies fit (Yesufu 1996). Due to brain drain, many institutions of learning are now producing half baked graduates, who are not able to deliver in their areas of specializations. Their impact on national economy in term of productivity is generally below the required standard for an underdeveloped economy. As a result of lack of competent hands in the tertiary institutions, enrolment of post-graduate students has equally declined as illustrated in table 6 .

Table 6. Post-Graduate awards by the Nigerian universities between 1988 and 1992

\begin{tabular}{|c|c|c|c|c|c|}
\hline Discipline & \multicolumn{5}{|c|}{ Years } \\
\hline & $\mathbf{1 9 8 8}$ & $\mathbf{1 9 8 9}$ & $\mathbf{1 9 9 0}$ & $\mathbf{1 9 9 1}$ & $\mathbf{1 9 9 2}$ \\
\hline Administration & 519 & 436 & 469 & 621 & 734 \\
Agriculture & 319 & 306 & 215 & 421 & 429 \\
Arts & 374 & 390 & 441 & 404 & 214 \\
Education & 1,751 & 2,055 & 1,229 & 1,972 & 1,062 \\
Engineer \& Technology & 275 & 217 & 305 & 226 & 112 \\
Environmental Design & 267 & 170 & 210 & 199 & 41 \\
Law & 121 & 138 & 181 & 226 & 08 \\
Medicine & 141 & 152 & 157 & 200 & 77 \\
Pharmacy & 28 & 15 & 19 & 12 & 06 \\
Sciences & 420 & 474 & 620 & 491 & 276 \\
Social Sciences & 849 & 881 & 1,127 & 1,218 & 847 \\
Veterinary Medicine & 87 & 14 & 18 & 17 & 12 \\
Others & Nil & Nil & Nil & 918 & Nil \\
\hline
\end{tabular}

Source: National University Commission cited in Oni (2010)

Brain drain has worsened the already depleted health care resources in Africa and widens the gap in health inequalities worldwide (Haines 2002). The departure of health professionals from Africa has eroded the ability of medical and social services to deliver even basic health and social needs in the region. For instance, thirty-eight of the 47 sub-Saharan African countries, including Nigeria fall short of the minimum World Health Organization (WHO) standard of 20 physicians per 100,000 people (Tebeje 2005). Physicians migrating from Nigeria to developed nations have accelerated dramatically over the last 20 years. In 2005, 1, 805 physicians, who graduated from five universities in Nigeria migrated to the United States of America, as indicated in table 7. 
Table 7. International medical graduates in the U S by top medical schools in Nigeria (2005)

\begin{tabular}{|c|l|c|}
\hline S/n & Medical School & $\begin{array}{l}\text { No. of physicians now practicing } \\
\text { in US }\end{array}$ \\
\hline 1 & University of Ibadan & 643 \\
2 & University of Lagos & 429 \\
3 & University of Nigeria & 394 \\
4 & University of Benin & 183 \\
5 & University of Ife & 156 \\
\hline \multicolumn{2}{|r|}{ Total } & 1,805 \\
\hline
\end{tabular}

Source: Hagopian et al (2005)

Dearth of health workers has badly affected the nation's health sector (Ojimadu 2007; Stilwell and Diallo 2003). It depletes an important element of the middle class (Hagopian et al 2005). Medical Doctors are regarded as important segment in the social and economic make up of the middle class, who are generally respected as being above corruption. They provide a market for consumer goods and contribute to political, social and economic stability of the country (Hagopian et al 2005). Moreover, poor persons who cannot afford overseas treatment for their patients are dying every day through sicknesses and diseases due to insufficient health workers in the country (Mason 2009). Other glaring effects in the sector are:

- Loss of Health Services: Healthcare professionals contribute to health promotion, disease prevention, diagnosis, treatment, and rehabilitation. Thus, the emigration of such professionals exacerbates the human resource shortages in national and district health systems and reduces the capability of such systems to perform their core functions.

- Loss of Supervisors: Practicing doctors and senior nurses normally play major roles in supervising staff in peripheral facilities in any given country that serve the majority of populations-such as health centers, dispensaries and health posts. Thus, when such doctors and nurses emigrate, the supervisory capabilities of a country's healthcare system are diminished, contributing to a further weakening of the capacities of the healthcare system to provide quality services to patients.

- Loss of Mentors for Trainees: There is a diminishing scope of mentoring junior researchers by seasoned and senior researchers due to brain drain (Okebukola 2002). In any given country, practicing doctors and senior nurses train and counsel new healthcare employees and students on houseman ship. Thus, exodus of such manpower assets can create a negative inter-generational effect on the process of health-related human capital creation in a country.

- Loss of Public Health Researchers: Many of a country's specialized doctors and nurses who may decide to migrate to other countries are often among the very few active researchers in local healthcare institutions.

These trends have sparked claims that African countries are dying a slow death from escalation of brain drain (Tebeje 2005). United Nations in particular believes that emigration of African professionals to the West is one of the greatest obstacles to her development. (Tebeje 2005).

\section{Theoretical Insights}

Existence of mankind without leadership is in vain in our society. Leadership is more or less like an engine that propels man's society to either advancement or backwardness. Ideas embedded in leadership, which makes it germane to this paper are heavily rooted in "Elite theory".

The paradigm erupted from the works Pareto (1963) and Mosca (1939) as a reaction to the view of Karl Marx on power and state. Karl Max postulates in his last stage of development, tagged communism that society will be governed by Marxist elites, who will distribute goods and services to the populace according to their needs and not wants. Instead, Pareto and his associates argue that communist party is not realistic. That only elite rule is inevitable in man society. Moreover, they contend against popular participation of people in politics. In that wise, the paradigm kicks against popular definition of democracy as the government of the people by the people and for the people as put forward by Abraham Lincoln. Although, Mosca (1939) agrees with Abraham Lincoln on Democracy being the government of the people and for the people, he however disagrees with him on the ground of democracy being the government by the people. For him, democracy can never be the government by the people. Olaniyi (1995:91), a scholar of elite extraction shares the same view with (Mosca 1939). According to him "to talk 
of government in which all take part in decision making is farce. What we have in practice is the government by a minority protecting the selfish interest of members to the detriment of the ruled".

Central to elite theory is that society is divided into two main groups; a ruling minority and the ruled. Minority monopolizes power by taking major decisions that affect the ruled. This is possible because elite owes its power to internal organization. It forms a united and cohesive minority against unorganized and fragmented masses (Mosca 1939).

In man's society, everybody cannot exercise power. Therefore, few people are vested with power while others are ruled. Those vested with power seems to be highly organized while the ruled are disorganized and find it intricate to present a common front to challenge the ruling elites. In underdeveloped societies, the ruling minority seize this opportunity to hold unto power perpetually and abuse the same. Such elite direct affairs of the society by formulating and implementing policies void of public interest. The structure of institutions in man's society such as major corporations; the military, federal, state and local government etc is such that those at the top of the hierarchy largely monopolize power to the detriment of those at the lower level (Mills 1956). These institutions occupy key pivotal positions in the society and elite comprises those who hold positions in these institutions (Mills 1956). They are not neutral social structures pursuing clear goals but arenas for conflicting interests in which the social issues and power relations of society are played out to the detriment of the masses (Hughes and Kroehler 2005).

This approach demonstrates the usefulness of leadership in our society. No nation can survive without leadership but how far a nation can survive and sustain its survival satisfactorily depends on the type of leadership prevailing in that nation. A country with poor leadership is doomed in the comity of nations worldwide (Omonijo 2008). Bad leadership seems to be the gateway to a failed state. Most countries in sub-Sahara Africa is regarded as failed states as indicated in table 8.

Table 8. Failed state index 2009 edition.

\begin{tabular}{|c|c|c|}
\hline $\mathbf{S} / \mathbf{n}$ & Countries & Ranking \\
\hline 1 & Somalia & 1 \\
2 & Zimbabwe & 2 \\
3 & Sudan & 3 \\
4 & Chad & 4 \\
5 & Democratic Republic of Congo & 5 \\
6 & Central African Republic & 8 \\
7 & Guinea & 9 \\
8 & Ivory Coast & 11 \\
9 & Kenya & 14 \\
10 & Nigeria & 15 \\
\hline
\end{tabular}

Source: Jude 2009

Nigeria is regarded as $15^{\text {th }}$ most failed state in the world according to 2009 edition of the ranking (Jude 2009). The implication in table 8 is that elites of these nations have failed completely in governing their nations properly. That is the social life reality of leadership in Nigeria and others underdeveloped societies, which elite approach has successfully pointed out (Hughes and Kroehler 2005). Elites who control power in these societies use it to purse their self motives to the detriment of the ruled (Bakoji 2006; Amokeodo 2004). Resources meant for development is often siphoned and embezzled by these elites (Omonijo 2008), leaving their countries impoverished, which galvanized poor economy, low level of industrialization, mass unemployment, high rates of armed robbery etc. These are facilitators of brain drain in underdeveloped countries.

However, inability of elite scholars to make a distinction between elites who manipulated power to their advantages and those whose who served their nations without any reservation is a major flaw against the paradigm. Even in underdeveloped countries, where poor leadership reigns supreme, it is noted that few elites had served their nations to the best of their ability (Omonijo 2008). Elites such as Dr. Nelson Mandela of the Republic of South Africa; late Julius Nyerere of Tanzania, General Buhari/Idiagbon of Nigeria etc are in this category. Hence, scholars like Olaniyi (1995) and Mill (1956) should be reminded that not all elites use their positions to satisfy self interests. 


\section{Methodological Issues}

This study employs primary and secondary means of data collection. Questionnaire and in depth interview were used as instruments of data collection. Questionnaires were applied to students while the in-depth interview aspect was applied to academic and non-academic staff. The questionnaire aspect presents five tables. It contains both open and closed ended questions. Table 1 features twelve questions, in which respondents were asked to rank items provided from 1 to 12 using a one way ranking scale. Table 2 contains one question, which instructs respondents to indicate their interest in travelling to developed nations after their study. Table 3 contained items relating to effects of brain drain in Nigeria. Also, respondent were asked to rank these items from 1 to 11 on a one way raking scale. Table 4 contains one question that has to do with poor leadership of the country. Respondents were asked to indicate whether escalation of brain drain in the country could be attributed to it. Three options- yes, no and don't know were provided. The last table contains 11 questions relating to solutions to the problem of brain drain in Nigeria. Respondents were asked to tick one best option known to them. In the open ended question, respondents were asked to indicate countries which they are planning to travel to after their study. This was applied to those who indicated their interest in travelling out of the country at the end of their study.

\subsection{Population and Sample Size}

Student body, academic and non-academic staff constitutes the population of this study. In The Bells University of Technology, the population of students is two thousand three hundred $(2,300)$ while that of staff is two hundred (200). In Crawford University, the population of students is one thousand two hundred and fifty $(1,250)$ while that of staff is one hundred and fifty (150) resulting in 3, 900 (three thousand nine hundred) all together. Out of this figure, six hundred and ninety-one (691) samples were drawn from the population. Six hundred and thirty-seven (637) students were drawn from the student body in the two universities while fifty-four (54) members of staff were selected.

Sample techniques

Proportional sample technique was employed in selecting respondents for the study. This method involves selecting from the population according to its size. Thus, the number of respondents to be selected depends on the population of each department. Bells University of Technology was divided into six (6) departments-Biological, Chemical and Physical Sciences, Centre for Foundation Education, Accounting and Economics while Crawford University is divided to 5 departments. Each department produced sample according to its population. A simple random sampling technique was used to select respondents from each department for the study. The same method was used in selecting interviewees among academic and non-academic staff.

a. Instruments of data analysis

Simple percentage and one way ranking scale was used to describe data collected. Moreover, chi-square was used to test hypothesis formulated. Furthermore, in-depth interview was used to complement the result obtained from simple percentage, ranking and chi-square

\section{b. Response rate}

650 questionnaires were distributed to the respondents but 637 were returned back to the researcher. That represents $98.9 \%$ of the distribution.

\section{Analysis and Results}

Results of data analyzed in this study are presented in table nine to fourteen. 
Table 9. Causes of brain drain in Niger

\begin{tabular}{|l|l|c|c|c|}
\hline S/N & \multicolumn{1}{|c|}{ Causes } & Frequency & $\mathbf{~ \% ~}$ & Rank \\
\hline 1 & Mass unemployment & 95 & 14.91 & 3 \\
2 & Mass poverty & 92 & 14.44 & 4 \\
3 & Poor leadership of the country & 110 & 17.27 & 1 \\
4 & Poor salaries and conditions of service & 100 & 15.69 & 2 \\
5 & Crises (political, religion, communal, education) & 73 & 11.46 & 5 \\
6 & Poor infrastructural facilities & 27 & 4.24 & 8 \\
7 & Poor recreational facilities & 15 & 2.35 & 11 \\
8 & Lack of opportunity for advancement & 12 & 1.88 & 12 \\
9 & Poor education facilities & 19 & 2.98 & 10 \\
10 & Poor health facilities & 29 & 4.55 & 7 \\
11 & Lack of good rewarding system for hardworking manpower & 43 & 6.75 & 6 \\
12 & Untimely death of manpower assets & 22 & 3.45 & 9 \\
\hline & Total & $\mathbf{6 3 7}$ & $\mathbf{1 0 0}$ & \\
\hline
\end{tabular}

Source: From the data collected by the researcher

Deducing from table 9, respondents rated poor leadership of the country as the major cause of brain drain highest with $17.27 \%$. This is followed by poor salaries and condition of service of manpower assets in the country with $2^{\text {nd }}$ position $(15.69 \%)$. Mass unemployment was ranked $3^{\text {rd }}$ with $14.91 \%$ while mass poverty was rated $4^{\text {th }}$ with $14.44 \%$. Crises in the country such as political, religion, communal and education were rated $5^{\text {th }}$ with $11.46 \%$. Lack of good rewarding system for hardworking manpower was rated $6^{\text {th }}$ with $6.75 \%$. Poor health, infrastructural, untimely death of manpower assets and recreational facilities were raked $7^{\text {th }}, 8^{\text {th }}, 9^{\text {th }}$ and $10^{\text {th }}$ with $4.55 \%, 4.24 \%, 2.98 \%$ and $2.35 \%$ respectively. Finally, poor education facilities and lack of opportunity for advancement was rated $11^{\text {th }}$ and $12^{\text {th }}$ position with $(1.88 \%)$. Opinions of students corroborate views of the majority of members of staff. Fifty $(92.6 \%)$ of them ranked poor leadership of the country highest. They argued that if good leaders were in place, other factors causing escalation of brain drain would have been gladly arrested. Just four of them $(07.4 \%)$ ranked lack of good rewarding system highest.

On the escalation of brain drain in Nigeria, opinion of respondents in item 3 as reflected in table 9 corroborates David (2005) while their views as expressed in item 4 is in line with (Oni 2010). Item 1 in the table agrees with Chandra (2008) while item 2 corroborates (Igbuzor 2007). Mass unemployment and abject poverty can prompt human capital to migrate to developed societies. Item 5 as expressed by respondents corroborates (Tettey 2007; Ajayi 2009 and Ibanga 2010). Crises arising from politics, education, communal clashes, religion etc have prompted many manpower assets to dissert Nigeria for developed nations. Views of respondents in item 12 corroborate Ogundele (2009), who regrets untimely death of many manpower assets in the country in questionable circumstances. For instance, the life of Dele Giwa and his great intelligence in journalism was terminated abruptly via a parcel bomb. Also, the life of Chief Moshood Abiola-a business mogul, the greatest African philanthropist, pillar of sport in Africa, a visionary who had great ideas to contribute to his country's development, Chartered Accountant and an advocate of reparation course in Africa was cut short suddenly (http://www.kind.org/mko_biography.html 2011; Africa Confidence 2011). The life of Ken Saro-Wiwa and his great scholarly skill as well as that of Chief Alfred Rewane and his entrepreneurial wealth were terminated abruptly. Elites in power were responsible for the death of most of this human capital. Armed robbers played prominent roles in terminating lives of many others. Ajayi (2011) lends credence to others who died via accidents due to bad roads in the country. This is enough to drive manpower assets out of Nigeria to developed societies, where they think they are safe. 
Table 10. Effects of brain drain on Nigerian economy

\begin{tabular}{|c|c|c|c|c|}
\hline $\mathbf{S} / \mathbf{N}$ & Effects of brain drain & Frequency & $\%$ & Rank \\
\hline 1 & Insufficient manpower assets to mount various institutions in the country & 105 & 16.48 & 2 \\
\hline 2 & Loss of tax of manpower assets to the migrated country & 30 & 4.70 & 9 \\
\hline 3 & Loss of investment in education of migrated manpower assets & 32 & 5.02 & 8 \\
\hline 4 & Loss of capital used to employ expatriates to replace migrated manpower & 41 & 6.43 & 6 \\
\hline 5 & Production of half baked graduates from higher institutions & 95 & 14.91 & 4 \\
\hline 6 & Decline in enrolment of post-graduate students. & 33 & 5.18 & 7 \\
\hline 7 & High lecturer / student ratio in tertiary institutions across the nation. & 101 & 15.85 & 3 \\
\hline 8 & High mortality rate & 11 & 1.72 & 10 \\
\hline 9 & Underdevelopment of the nation & 118 & 18.52 & 1 \\
\hline 10 & Loss of remittance of money sent by migrated manpower to foreign country & 53 & 8.32 & 5 \\
\hline \multirow[t]{2}{*}{11} & High level of illiteracy & 18 & 2.82 & 11 \\
\hline & Total & 637 & 100 & \\
\hline
\end{tabular}

Source: From the data collected by the researcher

Table 10 displays effects of brain drain on the economy of Nigeria. Respondents rated underdevelopment of the country $1^{\text {st }}$ with $18.52 \%$. This is followed by insufficient manpower assets to mount various institutions in the country with $2^{\text {nd }}$ position $(16.48 \%)$. High lecturer / students ratio was raked $3^{\text {rd }}$ with $15.85 \%$. Production of half baked graduates from Nigerian tertiary institutions was rated $4^{\text {th }}$ with $14.91 \%$. Next in the hierarchy is loss of capital used to employed expatriates to replaced migrated manpower assets, which was ranked $5^{\text {th }}$ with $6.43 \%$. Loss of capital used to employed expatriates to replaced migrated manpower assets comes next with $6^{\text {th }}$ position $(5.02 \%)$. Decline in enrolment of post-graduate students, loss of investment in education of migrated manpower assets, loss of tax of manpower assets to the migrated country, high rate of death of sick persons were rated $7^{\text {th }}, 8^{\text {th }}, 9^{\text {th }}$ and $10^{\text {th }}$ respectively. Finally, high level of illiteracy was rated last with $11(2.82 \%)$. Members of staff equally shared the same view with students. All of them ranked underdevelopment of the country highest, which represents 100\%

Views of respondents in item 9, table 10 agree with Tebeje (2005), who argued that "emigration of African professionals to the West is one of the greatest obstacles to Africa's development." Views of respondents in item 1 agree with Emeagwali (2009), who attributes the shortage level of manpower assets in Nigeria to brain drain. The country is indeed witnessing shortage of human capital assets to mount her various institutions. Effects of this are indicated in items 5, 6, 7, 8 and 11. The cumulative effect of these is indicated in item 9. When manpower assets who can develop Nigeria are scattered all over developed societies due to brain drain, the nation will remain underdeveloped.

Table 11. Students interest in travelling to developed countries after their study

\begin{tabular}{|c|c|c|c|c|c|}
\hline \multirow[b]{2}{*}{$\mathrm{S} / \mathrm{n}$} & \multirow[b]{2}{*}{ Institutions under study } & \multicolumn{3}{|c|}{ Students responses } & \multirow[b]{2}{*}{ Total } \\
\hline & & Yes & No & Don't know & \\
\hline 1 & Bells University of Technology & $268(42.07 \%)$ & $46(7.23 \%)$ & $36(5.65 \%)$ & $350(54.95 \%)$ \\
\hline 2 & Crawford University & $213(33.44 \%)$ & $30(4.70 \%)$ & $44(6.91 \%)$ & $287(45.05 \%)$ \\
\hline & Total & $481(75.51 \%)$ & $76(11.93 \%)$ & $80(12.56 \%)$ & $637(100 \%)$ \\
\hline
\end{tabular}

Source: From the data collected by the researcher

As indicated in table $11,75.51 \%$ of the entire sample indicated their intentions to travel to developed countries at the end of their study in Nigeria. Out of the figure, respondents from Bells University of technology represent $42.07 \%$ while that of Crawford University represents $33.44 \%$. Respondents who expressed their dislike for travelling abroad after their study represent $11.93 \% .7 .23 \%$ of them are in the Bells University of Technology while $4.70 \%$ are in Crawford University. Lastly, $12.56 \%$ of students sampled could not decide whether they would travel or not. $6.91 \%$ of them are from Crawford University while $5.65 \%$ is from Bells University of Technology. Commenting on this, thirty-five (64.81\%) members of staff did not see anything bad about students desire to travel out of the country at the end of their study; whereas nineteen $(35.19 \%)$ of them frank at it bitterly. According to them, the hope of the country 
is in their hand. They should be able to team up and wage war against poor leadership of the country that is been responsible for the escalation of brain drain.

Table 12 below presents the sum total of four hundred and eight-one students (75.51\%), who indicated their interest in travelling to eleven developed countries after their study in Nigeria.

Table 12. Country of choice of students who intend to travel after graduation.

\begin{tabular}{|c|c|c|c|}
\hline $\mathbf{S} / \mathbf{n}$ & Country & Frequency & $\mathbf{\%}$ \\
\hline 1 & United States of America & 103 & 21.44 \\
2 & United Kingdom & 94 & 19.54 \\
3 & Canada & 72 & 14.96 \\
4 & Italy & 58 & 12.05 \\
5 & Belgium & 45 & 9.36 \\
6 & France & 37 & 7.69 \\
7 & Germany & 24 & 4.98 \\
8 & Japan & 15 & 3.11 \\
9 & Turkey & 11 & 2.70 \\
10 & Australia & 09 & 2.29 \\
11 & Netherland & $\mathbf{4 8 1}$ & 1.88 \\
\hline \multicolumn{2}{r|}{} \\
\hline
\end{tabular}

Source: From the data collected by the researcher.

Opinions of respondents as expressed in table $11 \& 12$ indicate that students, who are undergoing training in higher institutions, are interested in travelling abroad after their programmes in Nigeria. The hope of every nation rests on her youth. If the youth are not interested in staying in the country due to the problem of brain drain, then the future is at stake. Reasons mentioned to justify their stand reflected in table 8. These points corroborate Chandra 2008, Igbuzor 2007, Tettey 2007, Ajayi 2009 and Ibanga 2010 on why manpower assets migrate to developed societies.

Table 13. Solutions to the problem of brain drain in Nigeria.

\begin{tabular}{|c|l|c|c|}
\hline S/N & \multicolumn{1}{|c|}{ Solutions } & Frequency & $\mathbf{\%}$ \\
\hline 1 & Good leadership of the country & 109 & 17.11 \\
2 & Mass employment opportunities & 85 & 13.34 \\
3 & Political stability (sound democratization process) & 74 & 11.61 \\
4 & Good salary and conditions of service for workers & 100 & 15.69 \\
5 & Good rewarding system for hard working staff & 92 & 14.44 \\
6 & Solid infrastructural facilities & 46 & 7.22 \\
7 & Solid health facilities, & 37 & 5.80 \\
8 & Solid recreational facilities & 25 & 3.92 \\
9 & Reduction of high level of poverty in the country & 19 & 2.98 \\
10 & Eradication of unnecessary crises in the country & 22 & 3.45 \\
11 & Eradication of high level of poverty salvaging the country & 28 & 4.39 \\
\hline & Total & $\mathbf{6 3 7}$ & $\mathbf{1 0 0}$ \\
\hline
\end{tabular}

Source: From the data collected by the researcher

Deducing from table 13, respondents put good leadership as the best solution to the menace of brain drain in Nigeria with $17.11 \%$. This is followed by good salary and condition of service for staff with $15.69 \%$. Next on the hierarchy is good rewarding system for diligence workers with $14.44 \%$ while mass employment for the populace takes the next position with $13.34 \%$. Respondents, who suggested political stability, solid infrastructural facilities, health facilities and eradication of high level of mass poverty in the country constitute $11.61 \%, 7.22 \%, 5.80 \%$ and $4.39 \%$ respectively. Finally, respondents who put forward eradication of unnecessary crises and solid recreational facilities in the country as their solutions to brain drain represent $3.92 \%$ and 3.45 respectively. The view of students is equally similar with the view of the majority of members of staff on this subject. All of them perceived good leadership as the major solution to the escalation of brain drain. These interviewees argued that if the issue of bad headship could be addressed, factors leading to the escalation of brain drain would be greatly addressed as witnessed in the present day Ghana. Since the enthronement of good leadership, deluge of problems prompting Ghana's 
manpower assets to scatter all over the world have been arrested to the barest minimum (Aduhene 2009). Hence, the menace of brain drain is no longer as serious as it was in the past.

Item 1 in table 13 indicates the best solution to the menace of brain drain in Nigeria (good leadership). Factors aggravating brain drain, which includes mass unemployment, religion, communal, political, education crises, poor salaries and condition of service etc are anchored on poor leadership in the country. If the nation can adequately address the question of poor leadership as suggested by respondents, items 2-11 will be expressly tackled and the problem of brain drain will be reduced.

\section{Testing of Hypothesis}

Hypothesis one

$\mathrm{H}^{1}$ : There is a relationship between poor leadership and brain drain in Nigeria

Table 14a. Relationship between poor leadership and brain drain in Nigeria

\begin{tabular}{|c|c|c|c|c|c|}
\hline Question & Institutions under & \multicolumn{3}{|c|}{ Students responses } & Total \\
\cline { 4 - 7 } $\begin{array}{l}\text { Do you think the escalation of brain } \\
\text { drain in Nigeria can be attributed to } \\
\text { poor leadership of the country? }\end{array}$ & study & Yes & No & $\begin{array}{l}\text { Don't } \\
\text { know }\end{array}$ & Row \\
\hline & $\begin{array}{c}\text { Bells University of } \\
\text { Technology } \\
\text { Crawford University }\end{array}$ & (a) 190 & (b) 125 & (c) 85 & 337 \\
\hline \multicolumn{2}{|c|}{ Total } & (d) 104 & (e) 78 & (f) 55 & 300 \\
\hline
\end{tabular}

Table 14b. Calculating data for hypothesis 1

\begin{tabular}{|c|c|c|c|c|c|}
\hline Cells & $\mathrm{f}_{\mathrm{o}}$ & $\mathrm{f}_{\mathrm{e}}$ & $\left(\mathrm{f}_{\mathrm{o}}-\mathrm{f}_{\mathrm{e}}\right)$ & $\left(\mathrm{f}_{\mathrm{o}}-\mathrm{f}_{\mathrm{e}}\right)^{2}$ & $\left(\mathrm{f}_{\mathrm{o}}-\mathrm{f}_{\mathrm{e}}\right)^{2} / \mathrm{f}_{\mathrm{e}}$ \\
\hline $\mathrm{A}$ & 190 & 155.5 & 34.5 & 1168 & 7.51 \\
$\mathrm{~B}$ & 125 & 107.4 & 17.6 & 309.76 & 2.88 \\
$\mathrm{C}$ & 85 & 70.1 & 14.9 & 222.01 & 3.17 \\
$\mathrm{D}$ & 104 & 138.5 & -34.5 & 1190.25 & 8.59 \\
$\mathrm{E}$ & 78 & 95.6 & -17.6 & 309.76 & 3.24 \\
$\mathrm{~F}$ & 55 & 65.9 & -10.9 & 118.81 & 1.24 \\
\hline \multicolumn{5}{|c|}{ Total } & $\sum 26.63$ \\
\hline
\end{tabular}

Chi-square $\left(\mathrm{X}^{2} \mathrm{cal}\right)$ value $=26.63$ and Chi-square tabulated $\left(\mathrm{X}^{2} \mathrm{tab}\right)$ value $=7.378$

$\mathrm{X}^{2}=\sum\left(\mathrm{f}_{\mathrm{o}}-\mathrm{f}_{\mathrm{e}}\right)^{2}$

$\sum \mathrm{f}_{\mathrm{e}}$

Where $x^{2}$ is chi-square, $f_{0}$ is frequency observed, $f_{e}$ is frequency expected, $f_{0}-f_{e}$ is the difference between the observed and expected frequency, $\left(f_{0}-f_{e}{ }^{2}\right.$ is the difference between the observed and expected frequency all squared. The degree of freedom is 2 while .025 is the level of significance.

The chi-square computed value of 26.63 is $>$ (greater) than the chi-square tabulated value of 7.378. As a result, the hypothesis that says there is a relationship between poor leadership of the country and escalation of brain drain is upheld. Our result here justifies the view of fifty $(92.81 \%)$ members of staff. They argued that most factors causing the escalation of brain drain are anchored on poor leadership of the country. As elites in government keeps on enriching themselves, the job market worsens day by day (Igwe 2011). Inflation, rising foreign exchange rate, and depreciating Nigerian naira continued to destroy the economy.

Thus, unemployment, poverty and hardship increased in cities, town and villages across the nation (Igwe 2011). This paved the way for human capital flight in the country. Therefore, moral decadence of many elites in government has its root in maladministration that leads to the escalation of brain drain in the country. Therefore, the fear of God, which is the beginning of wisdom, is absolutely lacked in the 
lives of many elites in positions of authority. When the fear of God is destroyed in one's life, wisdom needed for direction towards achieving excellence in government could be erased. That might lead to maladministration, which is the route to economy malady, political uproar and social ills.

\section{Findings}

Findings of this study indicate a relationship between poor leadership of the country and escalation of brain drain. Also, it shows that students are interested in migrating to the developed societies at the end of their study. Causes of the escalation of brain drain in Nigeria are: poor leadership of the country, poor salaries of workers and conditions of service etc. effects of brain drain on the economy of the country are: underdevelopment of Nigeria in the comity of nations, shortage of manpower resources, loss of tax to the country etc. Solutions to the problem of brain drain are: good leadership, good salaries and condition of service for staff etc.

\section{Concluding Remarks}

This study concludes that there is a relationship between poor leadership and brain drain in Nigeria. Moreover, it discovers that students are interested in travelling to developed nations at the end of their study. Causes of escalation are poor leadership of the country, poor salary and condition of service, mass unemployment, mass poverty etc. major effects of brain drain in Nigeria are, backwardness of the nation in the comity of nations, shortage of manpower to mount various institutions in the country, loss of tax of migrated manpower to developed countries, loss of tax of migrated manpower to foreign countries. Considering the above, one wonders why most elites in Nigeria keep on attributing the backwardness of the nation to colonialism and slavery. By this, they are ignoring devastating roles, which they are playing in this backwardness. This could be seeing as an escapist approach to shift their stupidity and foolishness on the colonial masters. More than slavery and colonialism, elites in Nigeria have contributed immensely to the backwardness of the nation. The newly Industrialized Countries of South East Asia were once colonized like Nigeria and at the same time backward in the comity of nations worldwide. Nevertheless, elites of these societies have been able to transform their countries from agrarian societies of yesteryears to industrialized ones of today. Nothing empowers than knowledge (Oyedepo 2009). It is an irony of life to realize that many custodians of knowledge, who could transform Nigeria are scattered all over the world due to the menace of brain drain. Thus, to create the future that Nigeria deserves, our elites need a huge shift in thinking, values, and action. Their shift in thinking from wrongs to rights is very crucial to the advancement of the nation.

\section{Recommendations}

Based on the above conclusion the following recommendations are made:

- Good leadership. Transparency in leadership is very important and it should be worked for seriously and maintained in underdeveloped countries. This will usher in good governance, which ensures merit system without favoritisms in various institutions in the country. Effective and efficient administration will make provision for equal distribution of resources.

- Solid economy. Sound economy has its root in high level of industrialization. This arrests unemployment among the masses and subsequently abject poverty. When manpower assets are well placed with better remunerations, their movement to developed nations will be reduced. Solid social, infrastructural, recreational facilities, road network equally emerge through a flourished economy. These make life convenient for manpower assets and the entire populace. Their availability could go a long way in reducing migration of human assets from underdeveloped countries.

- Education plays a powerful role especially in the growing problems of international migration of manpower assets and young intellects. Therefore, offering these individuals the necessary education qualifications in their home countries, and expanding a better educational infrastructure might prevent emigrants who are seeking a higher education abroad. This could also prevent those who are planning to stay permanently abroad after their education from doing so. 
- Offering higher wages for human capitals according to their qualifications is very essential. Furthermore, underdeveloped countries should shore up the qualities of their research institutes and provide research incentives for professionals. This could address issues of research integrity, professional development, and psychological satisfaction.

- General safety of lives and properties of the entire citizenry should be put in place. Crises political, religious, and communal as well as full scale wars should be avoided at all cost. These could forestall migration of manpower assets from leaving the country out of fear for their lives.

- Indiscriminate elimination of manpower asset should stop with immediate effect. Developed nations do protect their manpower assets from any attack that can take the worth of their knowledge away. They are preserved, encouraged and rewarded accordingly. Underdeveloped nations should follow suit.

\section{References}

Achebe, C. (1984). The Trouble with Nigeria. Onitsha: Africana-Fep. Publishers.

Adams, S \& Crawford, A (2000). World War ii. First edition. Printed association with the Imperial war Museum Eyewitness Book series. $\quad$ New York: Doring Kindersley Limited.

Aduhene, G (2009). Ghana: Leading a new era of Democracy in Africa. <http://demockracy.com/ghana-leading-anew-era-of-african-democracy> (Accessed on 24-07-2011)

African New Service (2000). Cost of Manpower Assets to African nations. April $8^{\text {th }}$.

Africa Confidential (2011). Nigeria: Chief Moshood Kahimawo Olawale Abiola (MKO Abiola)President-Elect 1993. $50(7)$

African Watch Committee (1990). Somalia: A Government at War With its Own People. New York, P. 9

Ajayi, F (2009). Book Reviewed: The Effect of Religion on the Political Process: The Case of the Federal Sharia Court of Appeal (1975-1990).

Ajayi, F (2011). [yorubanation] 'WAHALA DEY O! - 'YOU ARE HIRED! <"sobef650@aol.com" <sobef650@aol.com> (accessed on May 30, 2011)

Akande, L and Fagbemi, A (2009). Envoy Decries Illegal Migration to Holland. Nigerians and others Top the List of Asylum Seekers stjudehc@yahoo.com. Tuesday 27th of October. 2: 20pm

Ake, C (2001). Democracy and Development in Africa: Spectrum Books. Ibadan

Alexander, M (1980). The Nigerian Revolution and the Biafran War. $4^{\text {th }}$ Dimension Publishers Limited: Enugu.

Amnesty International (1984). Torture in the Eigbties. Bristol, England: Pitman press

Amokeodo, T (2004). "Africa Loses $\$ 400 \mathrm{bn}$ to Corruption-UN. Abacha, Mobutu top Looters' List. Punch, Daily volume 17, number 19,248 (December):1\& 4

Anugwom, E. E; Omonijo, D. O. \& Fadugba O. A (2011). A Review of Gender Performance of Graduating Students in a Private Christian Mission University in Nigeria Between 2008 and 2010. International Journal of Gender Empowerment and Development. 11 (1)

Anekwe, C (2009). Brain Drain: The Nigerian Experience. < http://www.niger deltacongress.com /barticles /brain _drain_the_nigerian_experie.htm.3> (accessed July 15, 2009)

Bakoji, S (2006). "All our Leaders are Corrupt-Ribadu". Independence, Daily. Volume 3, number.1012(July 19 th): $1 \& 5$.

BBC NEWS, (2002). Russian Brain Drain Tops Half a Million says Viktor Kalinushkin in an interview on Thursday June 20th $13: 34$ GMT

BBC NEWS (2002). Norway, Best Place to Live. Wednesday, July 24th. 17:14 GMT 18:14 UK

BBC NEWS, (2001). Brain Drain Costs Africa Billions. Tuesday July 10th. 9:56 GMT. 20:56 UK

Blackaby R and Blackaby H (2001). Spiritual Leadership. Kaduna: Evangel Publishers limited.

Braun, H (2004). Is Brain Drain a Problem in Germany? Politicians Offer their View $<$ http:/ $/$ www.Timeshighereducation.co.uk / story.asp?storyCode $=192272$ Sioncode $=26>$ accessed on $15^{\text {th }}$ of Aug.

Carrington W. \& Detragiache E (1998). How Extensive is the brain Drain. International Monetary Fund, 1 (36)

Chandra, P. (2008). Mathematical Formulation of Poverty Index. European Journal of Scientific Research, 10 (3)

David, H (2005). Africa Research Angers lecturers. Daily, Guardian. 28 $8^{\text {th }}$ of May.

Ejiofor, P.N (1984). Management in Nigeria: Theories and Issues. Onitsha: Africana-Fep. Pub.

Ekweme, J. (1998). Africa and Dictators. Daily Guardian. 15th of August. : 12

Emeagwali, P. (2009). How do we reverse the Brain Drain. The Nigerian Village Square2009 http://www.nigeriavillagesquare.comn /articles/philip-emeagwali/how-do-we-reverse-the-brain-drain13.html> (accessed January 14, 2010)

Farouk, C (2011). Who are Nigeria's Boko Haram Islamists? BBC African service < http://www.bbc.co.uk /news/world-africa-13809501> (accessed on $2^{\text {nd }}$ of August 2011)

Guardian Editorial (2010). Tragedy in Poland. Monday April $19^{\text {th }}: 1$ 
Girma, B. (2009). Brain Drain Costs Africa \$4 BLN Annually: UNDP. The Africa Monitor. September $12^{\text {th }}$.

Goodman, J (2007). Cuban Doctors Awaiting U. S Response. Washington Post. Feb. $2^{\text {nd }} \cdot$ p. 3

Haines, A (2002). Brian Drain and health professionals: A Global Problem needs Global Solutions. BMJ, 324 (2)

Hagopian, A; Ofosu, A; Fatusi, A; Biritwum, R; Esscl, A; Hart, G and Watts, C (2005). The Flight of Physicians from West Africa: Views of African Physicians and Implications for Policy. Elsevier Journal of social Science and Medicine, 61 (2005): 1750-1760

Harrison, F (2007). Huge Cost of Iranian Brain Drain. BBC News. Retrieved on Monday $8^{\text {th }}$ of January. 12:36 GMT Holy Bible (1967). Saint Mark of The Scofield Reference Bible. New York: Oxfor University Press

Hughes, M and Kroehler, C. J (2005). Sociology the Core. New York: The McGraw Hill Companies.

Http://www.sudaneseonline.com/cgi-bin/enews (2008). Definition of Brain Drain. Accessed November 15, 2008).

Http://www.answers.com/topic/braindrain. (2008). Definition of Brain Drain. (Accessed December 2009)

http://www.kind.org/mko_biography.html (2011). Chief Moshood Abiola and Reparation Course for Africa. Accessed and Retrieved on $7^{\text {th }}$ of April.

Mac-Gregor, J. B (1978). Leadership. New York: Harper Torch books.

Ibanga, I (2010). Police, JTF Move Into Ogoni as Two Communities Clash. Tribune, Daily 15 ${ }^{\text {th }}$ March: 8

John, G (1990). On Leadership. The free press: New York

Jude, S (2009) Failed State Index: Nigeria Ranked 15 out of 177 Nations. $<$ Yorubanation@yahoo.com $>$ (accessed July 8, 2009)

Igwe, C. N. (2011). Socio-economic Developments and the Rise of 419 Advanced-Fee Fraud in Nigeria. European Journal of Social Sciences, 20 (1):184-193.

Marx, K and Engels, F (1969). Selected Works. Moscow: Progress Publishers.

McLaughlin, D and Smith, D (2005). Doctors Go West in Polish Brain Drain: Crisis Loom in Warsaw as Medics Migrate to Britain in Search of Living Wage. Sunday observer. May $15^{\text {th }}$

Mills, C. W (1956). The Power Elite. New York: Oxford University Press.

Mosca, G (1939). The Ruling Class. New York: Mc Graw-Hill

Mgbanga, M (2008). The Problem of Brain Drain: Ultimately Socialism is The Answer. Nairobi, Kenya

Odetunde, C (2004). The state of higher education in Nigeria. Retrieved- (4/2/2004) http://www.Nigeriadeltacongress .com / article/state-of higher education

Offiong, D. A (2001). Globalization: Post-Neo dependency and Poverty in Africa. Enugu: Fourth Dimension Publishing Company Ltd.

Ogu, E (2008). Challenges Facing Nigerian Universities < http://nigeriaworld.co/articles/2008/sep/300 .htm> (accessed May 24, 2011)

Ogunde, T. (2009). Who Killed Dele Giwa. Famous People News. Com $2009<$ http://famouspeoplenews. wordpress.com /2009/06/11/who-killed-dele-giwa. (accessed June 11, 2010)

Ojimadu, D. E (2007). Human Resources Development For Health: Key to Achieving Millennium Development Goals. Retrieved from http://advocatehealth.blogspotspot.com/2007/02 /human-resurces developemt-for-health 07.html on September $4^{\text {th }}$. 18:05:59 GMT

Oropo. R. T (2009). Bayo Ohu, The Guardian Reporter, Murdered. Daily Guardian. Monday, Sept. $21^{\text {st. }}$

Oswald, S (1994). Spiritual Leadership. Moody Press: Chicago.

Osakwe, A. A (2002). "Application of Elite Theory to Corruption in the Nigerian Society" in O. T. Ugwu(ed.)Corruption in Nigeria: Critical Perspectives. Nsukka: Chuka Educational publishers: 67.

Oloko, P., Ibemere, D \& Ezeonyejiaku (2011). Nigerian Roads as Death Trap (Anger, pain, Tears as Nigerians Continue to Lose Lives and Limbs on Deplorable Roads). The Guardian. May 31st, 28 (11, 843): 15

Omonijo, D. O \& Okiti, O (2010). Patterns of Corruption in Power Holding Company, Awka. Journal of Nigerian Sociological Society, 2 (1)

Omonijo, D. O. \& Fadugba, O (2011). Parental Influence in Escalation of Examination Malpractices in Nigeria. European Journal of Social sciences. 19 (2): 297-307

Omonijo, D. O. (2008). Patterns of Corruption in Power Holding Company of Nigeria (PHCN), Awka. An Unpublished M. sc thesis, Department of sociology / Anthropology, faculty of Social Sciences, Nnamdi Azikiwe University, Awka

Onyekakeyah, L. (2005). University education and challenges. The Guardian Newspaper. Retrieved Sept. 20.

Oni, B. (2010). Capacity Building effort and Brain drain in Nigerian Universities. European Journal of social Research, 36 (2): $1-1$

Paterson, T (2007). German Brain Drain at Highest level since 1940. < http://www.independent.co.uk/news Lworld/euro.> (accessed June 1, 2010)

Paul, C.; Hoeffler, A. and Patitillo (2004). Africa; Exodus Capital Flight and Brain Drain as PortfolioDecisions. Journal of African Economies, 13 (1): 15-54

Pareto, V (1963). A Treatise on General Sociology ed. By A. Livingstone. New York: Dover Publications.

Reinstra, A (2009). Norway Rated World's Best Place to Live, Again. ICE News

Shinn D, H (2002). Reverse the Brain drain in Ethiopia. A paper Delivered to Ethiopian North America Health 
professionals Association on November 23, in Alexandria, Virginia: 1-6

Stenman, J (2006). Europe Fears Brain Drain to UK. CNN News. Retrieved on Wed. 28 th of June 10:35 GMT $(18: 35 \mathrm{HKT})$.

Stilwell, B and Diallo, T (2003). Developing Evidence-based Ethical Policies on Migration of Health Workers: Conceptual and Practical Challenges. Human Resources For Health, 1 (1): 8

Tebeje, A (2005). Brain Drain And Capacity Building in Africa. Association for Higher Education and Development (AHEAD) Ottawa, Canadaahead@headonline.org

The World's Worst Dictators (2010). Life magazine. < http://www.huffingtonpost. com/david-walle chinsky/the-worlds-worst-dictator_b_28679.html> (accessed April 15, 2011).

United Nations Development Programme (2001). Human Development Report 2001-Somalia. New York.

Ukuekue, G (1999). Lack of Reward for hardworking Nigerians. Daily, Guardian. July $5^{\text {th }}$.

United States of America Green Card Lottery (2011). Official U. S. Government Entry programme. Accessed on $<$ www.usadiversitylottery.com $>, 10^{\text {th }}$ of April

Veveros, A and Jackson, S (2006). Latin America Shouldn’t Bet Everything on Remittances. News and Broadcast, Press release No: 2007/121/LAC < http://90.worldbank.org/SMKLWSSIPO

Warren, B and Burnt, N (1997). Leaders: Strategies for Taking Charge. New York: Harper-Collins.

West, D (2003). How African Leaders Underdeveloped Africa. Daily Guardian. June $23^{\text {rd }}: 45$

Wilson, B (2005). Developing Countries See health Care Brain Drain. (Yorubanation)“St.jude" <stjudehc@yahoo.com.. Down loaded on Sunday August 2nd 2009 at 11:05pm.

Yesufu, T.M. (1996), The Nigerian Economy: Growth Without Development, Benin Social Science Series for Africa. 